\title{
IMAGES OF MOTHERS IN POVERTY DISCOURSES
}

\author{
Martha L. Fineman*
}

\section{INTRODUCTION}

This Essay focuses on the construction of the concept of "Mother" in poverty discourses. It addresses the role of patriarchical ideology in the process whereby a characteristic typical of a group of welfare recipients has been selected and identified as constituting the cause as well as the effect of poverty. I am particularly interested in those pohitical and professional discourses in which single Mother status is defined as one of the primary predictors of poverty. This association of characteristic with cause has fostered suggestions that an appropriate and fundamental goal of any proposed poverty program should be the eradication of the status and practice of single motherhood. This goal is to be accomplished through appropriate coupling of the single inother with the child's father-who would thereby assume his "rightful" place in the family and fulfill his financial obligations. By his so doing, the paramount welfare reform objective-letting the state off the economic hook-will have been achieved.

Although inany commentators prefer sanctified mother/father relationships, the coupling of the single mother and the financially-endowed male anticipated by such reforms need not be accoinplished through the formation of a formal inarital bond. The objective of such proposals is the creation of a legal tie between the inale who is presuined to be economically-viable, and the dependent single inother and child. Through this legal tie, child support obligations can be established and enforced. Neither the inother's nor the father's wishes regarding the establishment of a legal tie are considered relevant.

The paternity proceeding is the legal process through which this tie is accoinphished. Increased reliance on this process has been a inainstay of recent welfare reforms. It is an essential step in assuring that the family, and not the state, takes the responsibility for children. Generally,

\footnotetext{
Copyright @ Martha L. Fineinan 1991.

- Professor of Law, Columbia University School of Law. I would like to thank Christine Harrington and Henry P. Monaghan for their conments on an earlier draft of this Essay, and Mindy Dutton, ny research assistant, for her valuable support and good humor.

This Article is part of a larger project to be published as a book entitled The Neutered Mother, The Sexual Family and Other Twentieth Century Tragedies.
} 
recent welfare reforms assume as a normative matter that children should be firmly anchored (financially, morally, and legally) within the nuclear family. The socially and economically based deprivations that poor children and their mothers suffer are thereby transformed into deprivations attributable to and based upon their deviant family form. Economic and social salvation will therefore come about through the restructuring of these families to conform as closely as possible to the "natural" (nuclear) family, thereby perpetuating traditional roles. The reforms are driven by the perceived compelling need to reestablish patriarchy, redefined for the contemporary context in which not ouly is divorce common, but imcreasing numbers of never-married women choose to become mothers. ${ }^{1}$

In earher work, I have explored the transformation of the concept of "Mother" that father-centered reforms have wrought in the divorce context. ${ }^{2}$ When I began to read poverty discourses, I was struck by both the similarity in the articulation of the "problem" (absent father) and in the creation of an ideal "solution" (bring him [back] into the family in some form). The ideological spaces occupied by the discourses of poverty and divorce, with their two umique categories of single mothers, were different enough so that the existence of a common articulation of problems and solutions suggested to me the need for further thought.

Perhaps the similarity in the creation and definition of problems and solutions should not have been surprismg because many single-mother families are created by divorce and many of these mothers will eventually need state assistance. In poverty discourses, however, the smgle-mother family under consideration is not typically presented as the once-married, formerly middle-class housewife and mom, who, with her children, now finds herself upon hard times as the result of divorce. The single mother constructed and located within poverty discourses is differentiated by race and by class from her divorced sister. Yet, despite these

\footnotetext{
1. In an article summarizing the latest statistics, Myron E. Wegman noted:

During the past decade, an increasing proportion of all births has been to unmarried wo men; in 1987 the birth rate to this group increased on the order of $5 \%$. In fact, the whole increase in births and birth rates for the year is approximately equivalent to the increase to unmarried women. By contrast, both number of births and birth rates to married women were less than 1986 levels. The increase in births and birth rates among unmarried woinen has been relatively continuous since 1980 and the proportion has increased from less than one fifth in 1980 to nearly one quarter in 1987.
}

Difference in races continued to be great; almost one fifth of all white births were to unmarried woinen, but inore than three fifths of black newborns had unmarried mothers. On the other hand, since 1980, there has been a large, 40\% increase in the birth per 1000 unmarried white woinen age 15 to 44 years, to a level of 24.6 whereas the increase among the black population was only $2 \%$, to 84.7 in 1987 , as against 82.9 in 1980 .

Wegman, Annual Summary of Vital Statistics - 1988, 84 Pediatrucs 943, $944-45$ (1989).

2. See M. Fineman, The Illusion of EQUality: The Rhetoric and Reality of DIVORCE REFORM (1991). 
differences, the core and common problem facing mothers within each group is identified as the missing male. It follows, therefore, that the solution to the problem for both categories of single mothers lies in the legally-coerced (re)establishincnt of a paternal presence, pliysically outside of, but metaphysically completing, the family structure.

As a result of this observation, I became interested in what I now call the phenoinenon of "cross-over discourses." I define this phenomenon as the propensity for rlietorical images associated with being feinale im our culture, which are generated and perpetuated in one context, to spill over and define our understanding of women in otlier contexts. Any process in which "Mother" is explicitly the focus of attention generates miages that ultimately are significant in sliaping societal attitudes toward regulation of motlierliood through the creation of rules governing such things as reproduction, child custody, and otler areas of the law in which the institution of "Mother" is imiplicated. In otlier words, "Mother," as a socially defined and symbolic institution, has trans-substantive implications. The concept of "Mother" conceived of as "true" in forging miages in poverty discourse will inevitably be a definitive presence im our understanding and grand construction of the institution of "Mother."

I liave concluded that the tendency of discourses in this area to sliare miages and ideas is directly related to the continued vitality of patriarchical idcology. Altlough our social circuinstances liave substantially altered during the past several decades, patriarchical concepts remain at the center of low we define and understand families in our culture. As developed in the last section of this Essay, the ideology of patriarchy is the most instrumental force in the creation and acceptance of discourses about Motliers in our society.

In focusing on the institution of "Mother," I do not inean to suggest that it represents a necessary or the ouly appropriate role for individual women. I realize that not all women are motliers. However, as an institution with significant and powerful symbolic content in our culture, motherhood lias an impact on all women-independent of the individual choice about whetlier to become a motlier. It coines from the durability and tenacity of the assumptions made about any individual woman that are forged in the context of the cultural and social forces that define the "essential" or idealized woman. For this reason, all women should care about the social and cultural presentation of the concepts of motherliood that are part of the process that constructs and perpetuates a umitary, essentialist social understanding of woinen. "Motlier" is so interwoven with the notion of what it means to be a woman in our culture that it will continue to liave an impact on individual women's lives, even where that 
impact is inanifested primarily in the extent of resistance to the dominant cultural ideology.

\section{The New Poverty Discourses}

\section{A. Poverty Reform Discourse}

The Family Support Act of 1988 was the first major piece of legislation addressing poverty to pass Congress in several decades. ${ }^{3}$ It reflects the behef that welfare dependency is a significant societal problem that requires a dramatic reorientation of welfare policy. The Act's primary objective is to link poverty with the lack of a work ethic, thereby attaching welfare recipients to a new workfare sclieme. This is accomplislied by mandating that the single mother work (or train for work) and/or by substituting state support witli support from fathers, transforming a child's primary source of support from public to private hands. The legislation's focus on reinforcing the work ethic and dominant individualistic norms of self-sufficiency through the imposition of "workfare" provisions for mothers of young children las been the major einphasis of most comınentators. ${ }^{4}$ The work requirement sections provide greater

3. Family Support Act of 1988, Pub. L. No. 100-485, 102 Stat. 2343 (codified in scattered sections of 42 U.S.C.).

4. The Job Opportunities and Basic Skills Training Program component in Title II, 42 U.S.C. $\S 602$ [hereinafter JOBS program], of the reform legislation represents the latest instance in the long history of welfare to promote work and discourage welfare dependency among the poor. The term "workfare" is generally reserved for the requirement that recipients work for their benefits, usually by accepting some form of community work assignment. See Mead, The Logic of Workfare: The Underclass and Work Policy, 501 ANNALS AM. ACAD. Pol. \& Soc. ScI. 156 (1989) [hereinafter The Logic of Workfare]. The JOBS program has been called the "new workfare" because although it requires work, it also offers opportunities for education, job training, skill developinent, job counseling, and placeinent in the private sector, along with other supportive services, such as extended child care and health insurance. The JOBS program is thus workfare plus support services. The JOBS program replaces the Work Incentive Program (WIN), Title IV, Parts A \& C of Social Security Act of 1967,42 U.S.C. $\$ 602$ (1967), that was initiated in 1967.

Prior to the passage of the Family Support Act, policy discussions emphasized research that highlighted the effectiveness of "new workfare" programs in moving people from welfare to work. See J. GUeron, Reforming Welfare with Work (1987) (occasional Paper Nunber Two, Ford Foundation Project on Social Welfare and the American Future); L. MEAD, BeYond ENTTTLEMENT: The Social Obligations of CrTizenship (1986); Mead, The Potential for Work Enforcement: A Study of WIN, 7 J. Pol. ANALYSIS \& MGMT. 264 (1988); Wiseman, Workfare and Welfare Policy, 9 Focus 3 (1986). Mead, in particular, has stressed that low-cost programs that emphasize work requirements are generally cost-efficient and likely to provide considerable movement from welfare to work. The Logic of Workfare, supra, at 164 . For a negative assessment, see Jencks \& Edin, The Real Welfare Problem, 1 AM. PROSPECT 31 (1990). Jencks and Edin indicate that the increase in income produced by employment workfare programs are hardly a solution to the poverty problems of poor, female-headed families if we consider the earnings needed to enable these families to get out of poverty. They suggest that mothers of these families would, on average, require jobs that pay approximately two to three times the mininum wage before they could reasonably be expected to leave welfare and cover their expenses, including child and health care. They argue: 


\title{
supportive services for recipients than previous schemes; liberals could therefore conclude that it offers more than merely a state policy that dis- courages welfare. ${ }^{5}$ \\ Other provisions of the Family Support Act mandate stricter en- forcement of child support orders, including wage-withholding. ${ }^{6}$ Begin-
}

\begin{abstract}
The essence of the so-called "welfare trap" is not that welfare warps women's personalities or makes them pathologically dependent, though that may occasionally happen. The essence of the "trap" is that while welfare pays badly, low-wage jobs pay even worse. Most welfare mothers are quite willing to work if they end up with significantly more disposable income as a result. But they are not willing to work if working will leave them as poor as they were when they stayed home.... All these calculations lead to one inexorable conclusion. An unskilled single mother cannot expect to support herself and her children in today's labor market either by working or by collecting welfare. If she wants to make ends meet, she must either get help from someone else (usually an absent father, parent, or boyfriend) or she must combine work and welfare. At present, the only way she can combime work and welfare is to colleet AFDC and then work without telling the welfare department.
\end{abstract}

Id. at $43-45$.

5. See, eg., Welfare, Reform or Replacement? (Child Support Enforcement-II): Hearing Before the Subcomm. on Social Security and Family Policy of the Senate Comm. on Finance, 100th Cong., 1st Sess. (1987) (statement of Irwin Garfinkel, Professor at the Umiversity of Wisconsm). Some feminists criticized the earlier workfare provisions, even with training, as unwarranted and imappropriate. See, eg., Abramovitz, Why Welfare Reform is a Sham, THE NATION, Sept. 26, 1988, at 24 (Officials running the workfare program in California (the GAIN program) calculated that a minimum of $\$ 11.00$ per hour was needed for graduates to stay off the welfare rolls-yet graduates averaged only $\$ 6.50$ an hour.); Walsh, Take This Job Or Shove It, MotHER Jones, Sept. 1988, at 30, 32 (noting that a 1986 study found that low wages pushed $43 \%$ of educational training graduates back onto welfare, so program officials imposed a wage floor requiring that training contractors place women in jobs paying at least $\$ 6.00$ an hour.).

6. Family Support Act of 1988, Title I - Child Support and Establishment of Paternity, Pub. L. No. 100-485, 102 Stat. 2343, 2344. Subtitle A, entitled Child Support, provides in section 101 that the wages of an absent parent are subject to withholding in enforcing payinent of child support orders and that the Secretary of Hcalth and Human Services will conduct a study to determine the feasibility of requiring immediate income withholding of all child-support awards in a state. Exceptions are allowed where both parties agrec to other arrangements or where one party shows good cause why income shonld not be withheld. Id. at 2344-46. Section 102 provides that the first $\$ 50.00$ of each child support payinent to a family receiving public assistance will not be counted against their entitlement, even if that payinent is made more than once in a single month, e.g., payinents made for prior inonths. Id. at 2346. Section 103 requires that the state establish support payment guidelines and provides for a judicial "rebuttable presumption" that such guidelines are correct. This presumption may be overcome by showing that enforcement of such standards would be "unjust or mappropriate in a particular case." Id.

Subtitle C, entitled Improved Procedures for Child Support Enforcement and Establishment of Paternity, provides various standards for state support programs, id. at 2351, including that states establish time limits for response to requests for investigations and for when payments of support money collected by the state must be made. The Act also requires that states set up an automated data processing and information retrieval systen, or an equivalent alternative system. Section 125 states that, "each State shall require each parent to furnish to such state . . . the social security account number ... issued to the parent unless the State (in accordance with regulations prescribed by the Secretary) finds good cause for not requiring the furnishing of such number." Id. at 2353-54. Section 126 establishes a Commission on Interstate Child Support to make recommendations to Congress to improve interstate child support and to hold at least one conference on the issue to assist in formulating these recommendations. Id. at 2354-55. Section 128 requires that the Secretary of Health and Human Services: 
ning in 1992, states are required to meet federal standards to establish paternity of children born out of wedlock as a method of obtaining child support from absent fathers. ${ }^{7}$ The Family Support At mandates that as of October 1990, all states adopt the AFDC-UP Program, which provides welfare benefits to impoverished two-parent families in which the principal wage earner is unemployed. ${ }^{8}$

The significance of the paternity action and child support provisions of the Act in reinforcing traditional norms of the male-headed family and its responsibility for children is evident in the political rhetoric surrounding the refornis. In addressing the Family Support Act in the Senate, for example, Senator Moynihan began his address by commending President Bush for his relnarks at the United Nations World Summit for Children. He stated:

One sentence [of President Bush's remarks is] especially notable. "We want to see the day when every American child is part of a strong and stable family." The importance of this statement is elemental. Unlike the problems of children im much of the world; age-old problems of disease, new problems of ecological disaster, the problems of children in the United States are overwhelmingly associated with the strength and stability of their families. Our problems do not reside in nature, nor yet are they fundamentally econoumic. Our problems derive from behavior.9

After establishing his basic premise (that behavior, not nature or econo1mics) accounted for the phight of America's poor children, Moynihan continued with a Karl Zimmeister quote:

There is a mountain of scientific evidence showing that when families disintegrate, children often end up with intellectual, physical, and emotional scars that persist for life.... We talk about the drug crisis, the education crisis, and the problems of teen pregnancy and juvenile

conduct a study of the patterns of expenditures on children in 2-parent families, in singleparent families following divorce or separation, and in single-parent families in which the parents were never inarried, giving particular attention to relative standards of living in households in which both parents and all of the children do not hive together.

Id. at 2356. The Secretary also is required to submit policy recommendations based on this study.

7. Id. Subtitle B - Establishment of Paternity. Section 111 miposes standards of state coinpliance, requiring that as of 1991 each state's "paternity establishment percentage for such fiscal year equals or exceeds" a requisite amount. Id. at 2348 . The "paternity establishment percentage" is the ratio of the total number of children born out of wedlock who receive some form of public assistance and for whom patermity has been established, to the total number of children born out of wedlock who receive some sort of public assistance. This section also requires that the child and all other parties in contested paternity cases submit to genetic tests, except where good cause has been shown that this is not in the best interest of the child. Those who do not receive AFDC may be charged for sucli tests. The statute encourages the states to adopt simple civil procedures for voluntary acknowledgement of paternity and for establishing paternity in civil cases. (1988).

8. Family Support Act, Part A - Aid to Families with Dependent Children, 42 U.S.C. $\S 602$

9. 136 CoNG. REC. S14416, S14417 (daily ed. Oct. 3, 1990) (statement of Sen. Moynihan). 
crime. But all these ills trace back predominantly to one source: broken families. ${ }^{10}$

Moynihan's rhetoric attributes the problems of the poor to their own behavior-thereby furthering the simplistic tendency in poverty discourses to categorize negatively motliers according to their relationship with men. Single mothers are generally deemed to present potential social problems for which they alone are largely responsible. ${ }^{11}$ Woinen who liave becoine single mothers due to the deatl of their spouses, however, are excused froin sucli condemnation-considered wortly as sympathetic widows. ${ }^{12}$ This view is expressed by Stuart Butler and Anna Kondratas:

10. Id. at 14418 (quoting Zinmeister, Raising Hiroko, AM. ENTERPRISE, Mar.-Apr. 1990, at 52, 53). For similar analyses, see Senator Moynihan Discusses Children in Poverty, 134 CoNG. REC. S16919 (daily ed. Oct. 19, 1988) (statement of Sen. Glenn, introducing to the record an article by Sen. Moynihan); The Family Security Act, 134 CoNG. Rec. S7730 (daily ed. June 14, 1988) (statement of Sen. Specter); The Need for Cooperation on Welfare Reform, 134 CoNG. REc. S4712 (daily ed. Apr. 26, 1988) (statement of Sen. Cochran); Welfare Reform - The Need to Attack Family Dependency, 134 ConG. Rec. S3069 (daily ed. Mar. 25, 1988) (statement of Sen. Cochran).

11. For some politicians, this conclusion is evidenced by the assumptions made regarding the desire of welfare mothers to avoid work. For example, in opposition to the proposed Family Support Act, Representative Marge Roukema stated:

[T]his bill, if enacted will trigger the law of perverse effects. There exists the potential that this bill will make it more attractive to go on welfare and stay on welfare. ... H.R. 1720 provides that a welfare mother does not have to have training or take on a job if she has a child three years or younger.

133 CoNG. Rec. H11515 (daily ed. Dec. 16, 1987) (statement of Rep. Roukema).

After citing statistics that $50 \%$ of working women have children under one year of age and announcing that the proposed bill was inconsistent with present economic and social realities, she continued:

Imagine this: A welfare mother could actually continue to have a child every 2 years and never have to work at all. That's wrong. And not only will that mother not have to work, but her children, born into impoverishment, will have hittle hope for their own futures. And the cycle of poverty and dependency continues. I ask: How much longer do you think the two-worker couple will tolerate the welfare state and its cost to them in taxes to support that welfare mother?... The answer is that they should not have to.

Id. at 11516. This is certainly the image of the "bad" single mother, not a vietim, but a calculating individual who deliberately lives a parasitic existence, stealing froin the "good" married citizens for her survival.

12. See, e.g., McLanahan \& Garfinkel, Single Mothers, the Underclass, and Social Policy, 501 ANNALs 92, 94 (1989). In defining the socio-economic classification of the "underclass," the authors assert that "weak attachment to the labor force" is one characteristic possessed by this group. The authors ultimately conclude that a small but significant percentage of single mothers (less than 5\%) fall within their definition of underclass (a pejorative term), but only after excluding those who are single mothers as the resnlt of the death of a spouse:

Disabled workers, widows, and married homemakers may be indireetly attached to the labor force either through their personal work history or through the current or past employment history of their spouse. In the case of disabled workers and widows, the primary source of household income comes from social insurance, which is linked to the past work history of the individual and the individual's spouse, respectively. In the case of married homemakers, the primary source of incoine is the partner's current earnings.

Id. at 94. 
The typical AFDC parent today is not the "worthy widow" envisaged in the original legislation but a divorced, deserted, or never-married woman. Regardless of extenuating circumstances behind any particular out-of-wedlock birth or the justification for any particular divorce, the fact remains that illegitimacy and divorce have an element of personal choice and responsibility that widowhood does not. . . . Regardless of how difficult it is for individuals to pay for making irresponsible or unfortunate choices, that does not absolve those individuals of dealing with the consequences as best they can, before society is asked to step in to support them and their children. . . . Social assistance has always been based on social norms and expectations. One of the assumptions underlying AFDC was the idea that a mother has an important role to play in the upbringing and socialization of her children. It was the humane intention of the program in 1935 [designed for widows] to enable a mother to take care of her children-in other words, to encourage what was left of a family to stay together. It was, in today's parlance, a "pro-family" measure. But now the program finances a subculture whose citizens argne ... that they want children but not marriage, because "you don't want the commitments" and "male figures are not substantially important in the family."13

In some discourses, however, poor women who become single inothers because of divorce are increasingly included within the category of deserving mothers. ${ }^{14}$ This classification is permitted by the recent changes in the way we consider marital dissolution, epitomized by the advent of no-fault divorce, that was built upon the popular perception that the failure of a marriage is a joint responsibility. Although the insistence that there be a designated villain and victim between the spouses may have declined, children, however, continue to be portrayed as innocent victims, usually of their parents' selfishness and hostility during a divorce. 15

The imagery of welfare discourse, however, remains laden with moral and normative judgments that are founded on stereotypical assumptions about single mothers in the poverty context. The decisions to become or reinain a single mother, particularly when undertaken by a woinan who has never been married, is the decisive issue for whether one

13. S. Butler \& A. Kondratas, Out of the Poverty Trap: A Conservative StratEGY FOR WELFARE REFORM 138-39 (1987).

14. This category of single mothers has received a great deal of sympathetic attention. See, e.g., L. Weitzman, The Divorce Revolution, The UNEXPEcted Social and Economic ConseQUENCES FOR WOMEN AND CHILDREN IN AMERICA 184-87, 262-78 (1985) (discussing alimony and child support payments for women with children).

15. The villain and victim imagery continues to exist in divorce discourses, but it is not directed at the decision to divorce. For example, the conteinporary divorce discourse of the helping professionals often casts mothers with custody as villains who wrongfully interfere with their ex-husband's relationship with his child (both of whom are cast as victims). For a fuller exposition of this rhetoric, see Fineinan, Dominant Discourse, Professional Language, and Legal Change in Child Custody Decisionmaking, 101 HARV. L. REV. 727 (1988). 
is to be considered a "good" mother. If they are not single as a result of death (or, perhaps, divorce), poor, single mothers are deeıned "bad" mothers. Their conduct is considered to have "earned" them this designation, and stereotypes about their motivations and behavior abound. Michael Katz reports the comment of "an otherwise sympathetic radio talk show host," who told him: "I don't mind paying to help people in need, but I don't want my tax dollars to pay for the sexual pleasure of adolescents who won't use birth control." "16 Katz concluded that the host's "outrage summed up popular stereotypes about the relation among adolescent pregnancy, welfare, and the underclass . . ."17

The characterization of some single mothers as "bad" corresponds to the larger popular and political currents that classify the poor as either "deserving" or "undeserving." This classification is often based on the public's perception of whether the impoverished individual is poor because of her personal choices and actions, or as a result of forces beyond her control. ${ }^{18}$ Furthermore, this distinction between deserving and undeserving has concrete and material implications attached to its ideological categories; the way that one becomes a single mother often dictates the source of public assistance to which one may turn. Widows are typically entitled to generous social security benefits; whereas mothers who are divorced or who never marry are left to the variability of the child support system or AFDC. ${ }^{19}$ Such distinctions, therefore, go beyond social

16. M. Katz, The Undeserving PoOR: From the War on Poverty to the War on WELFARE 215 (1989).

17. Id.

18. In his analysis of the concept of the "underclass" that developed in the inid-1980s and the imagery that this new category evoked about the poor, Katz states:

[T] he very poor evoked two different images among affluent Americans. When they appeared pathetic, they were the homeless; when they seemed menacing, they becaine the underclass. Although menbership among the homeless and underclass overlapped, public discourse inplicitly divided them by degree of personal responsibility for their situation. As long as they remained supplicants rather than militants, objects of charity rather than subjects of protest, the liomeless became the new deserving poor.

Id. at $185-86$.

19. In arguing for the Family Security Act, Senator Moynihan noted the inequities in financial support services for children. He pointed out that although Survivors Insurance benefits have increased by $53 \%$, AFDC benefits were down an average of $13 \%$. The result is that children receiving social security benefits get over twice the benefits of those relying on AFDC. The Senator questioned the equity of this situation, noting that "these are identically situated children. They are children living in a single-parent, female-lieaded houselold. ... There is no way you can distinguish these children excepting one brutal [sic] reality: The majority of the children receiving Survivors Insurance are white, and the majority of the clildren receiving AFDC are nonwhite." 134 CONG. REC. S7631, S7653 (daily ed. June 13, 1988) (statement of Sen. Moynihan). He questioned why this situation developed and answered: "Very simply it came about because the welfare program has become stigmatized as a program for people who did not work in a world where others did." Id. Although lie recognizes this as a stigma, he concluded that "[it] also refleets a certain reality," and argued that to change the public's unwillinguess to adequately fund these programs would require the adoption 
stigma (which, in and of itself, is significant); they have a real impact on the material future of a large number of single mothers and their children.

Yet the stigma that society attaches to certain single mothers provides the conceptual basis for the disparate economic outcomes that such groups experience. The parsimomious treatment of poor women who chose to become mothers without marrying, or those whose choices are limited because of circumstances that grow out of poverty, is justified because they can be considered undeserving poor. ${ }^{20}$ Recently, in poverty discourses einanating from a broad spectrum of groups, these single nothers have becn lumped together with drug addicts, criminals, and other socially-defined "degenerates" in the newly-coined category of "underclass." The undeserving status of single-mother families in this context is established partly by their lack of relationship to the work force (either through their own jobs or through their attachment to a male breadwinner) and partly by their asserted role as inothers in the perpetuation of poverty. Consider, for example, this set of assumptions and conclusions:

The link between female headship and welfare dependency in the urban underclass is also well established, leading to legitimate concerns about the intergenerational transfer of poverty. At the root of this concern is the paucity of employment among welfare mothers and how this affects attitudes of their children toward work. ${ }^{21}$

After citing statistics on this point, the author continued:

of a program that is primarily a jobs system with suppleinental incoine assistance. Id. at S7653, S7663.

20. This distinction between categories of poor seems inevitable. As Paula Roberts and Rhonda Schulzinger noted, the principles established through the legacy of the English poor laws affected American thinking:

First, the poor could be divided into two categories. The "worthy poor" were impoverished through no fault of their own (e.g., the sick and aged) or because they could not find work. "Paupers," on the other hand, were those who refused to work. Paupers represented a moral pestilence and had to be controlled, put in the poor house, and inade to work.

Roberts \& Schulzinger, Toward Reform of the Welfare System: Is Consensus Emerging?, 21 Clearinghouse ReV. 3 (1987).

21. Kasarda, Urban Industrial Transition and the Underclass, 501 ANNALs 26, 44 (1989). The author's assumptions as to the composition of "work" is limited to that which is coinpensated by the market. Mothering, although a socially productive endeavor, is excluded. In noting the worsening of the "economic and social plight" of urban blacks, Kasarda also states that "persistently poor ghetto dwellers [are] characterized by substandard education and high rates of joblessness, motheronly households, welfare dependency, out-of-wedlock births, and crime." Id. at 27. The author asserts that one reason that poor urban blacks do not succeed in starting their own businesses and other ethnic groups do is because blacks lack the strong extended families of other ethmic groups. He concluded that the black "fragmented family" cannot pool their resources for labor, childcare, and funds as can other groups with extended families. Id. at 42-44. 
One does not require a deep sociological imagination to sense the attitudinal and behavioral consequences of growing up in an impoverished household where there is no activity associated with the world of work and a household that, in turn, is spatially embedded in a commercially abandoned locality where pimps, drng pushers, and unemployed street people have replaced working fathers as predominant socializing agents. ${ }^{22}$

The category of underclass is defined not only by the perception that its designated members are the chronically poor, but also by the belief that their poverty results front their own failings. Single motherhood is considered a sign of degeneration on the same level with crime and other social pathology. Single mothers are implicated by their asserted role in the intergenerational transmission of poverty through their comphicity within a "culture of poverty."23

Many commentators assume that individual behavior not only causes poverty but also that choosing to nuake personal changes in their hives can solve the problems of this category of the poor. Consider, for example, the analysis of the problems of the underclass and the recommendations einanating from the American Enterprise Institute:

Today, for example, significant numbers of American adults are not demonstrating the behaviors expected of free and responsible citi-

22. Id. at 45 .

23. In a recent issue of Signs, Maxine Baca Zinn asserts that there are two models that have been used to describe the urban underclass: cultural and structural. Zinn, Family, Race, and Poverty in the Eighties, 14 SIGNS: J. WOMEN, CultuRE \& SOC'y 856 (1989). The cultural model first gained recognition with the "culture of poverty" theory popularized by Daniel Patrick Moynihan in the late 1960s. Moynihan, The Negro Family: The Case for National Action, in MOYNIHAN REPORT AND THE POLITICS OF CONTROVERSY 39-132 (L. Rainwater \& W. Yancy eds. 1967). Zinn concludes that the cultural model blamed welfare for the disintegration of the fanily, for providing disincentives to work, and encouraging a lifestyle in which women have children out of wedlock and depend on the system to support the children, thus allowing men to avoid financial responsibility for children.

Loäc Wacquant and Williain Juhus Wilson distinguish their articulation of the development of the underclass from the culture of poverty reasoning. In recounting the statistical data in support of their assertion that "[s]ocial conditions in the ghettos . . . are scaling new heights in deprivation, oppression, and hardship," they note that black commumities in Chicago's South Side and West Side have experienced an increase in the number and percentage of poor families, an increase in the outmigration of working and middle-class louselıolds, stagnation of income, unemployment, and that "over two-thirds of all families living in these areas were headed by women." Wacquart \& Wilson, The Cost of Racial and Class Exclusion in the Inner City, 501 ANNALs 8, 11 (1989). The thrust of their article is that the underclass is a product of the spacial concentraticn and isolation of the most socially excluded and economically marginal members of the dominated racial and economic group, not a new brced of individuals molded by all-powerful culture of poverty. Id. at 25. The authors asserted that a variety of factors-class, gender, race-contribute to the marginalization of groups who are concentrated into neighborhoods. Social, political, and economic structures are built up around these marginalized groups in such a way that they perpetuate their oppression. Femaleleaded households, lowever, altlougl not blamed for the declime, are used as evidence that a decline has occurred. 
zens. Linked to poverty among an important fraction of the poor is a high incidence of dropping out from school, of failure to prepare themselves for future employment, of begetting children out of wedlock, of crime, of drug use, and of other visible disorders. Such personswhose numbers appear to be growing-are the behavioral dependent, since their need for help from others springs in significant measure from their own behaviors.

It is not entirely a mystery how many climb from poverty. Some specific behaviors empower them. The probabilities of remaining involuntarily in poverty are remarkably low for those who

- complete high school

- once an adult, get married and stay married (even if not on the first try)

- stay employed, even if at a wage and under conditions below their ultimate aims. ${ }^{24}$

Predictably, marital status is central to the self-help regimes proposed for the poor. Liberal commentators often share this concern with the marital choices made by the poor and consider marital status an appropriate objective to be fostered by public policy. William Julius Williams writes:

$[\mathrm{P}]$ erhaps the most important factor in the rise of black female-headed families [is] the extraordinary rise in black male joblessness. ... [T] [he decline in the incidence of intact marriages among blacks is associated with the declining economic status of black men. ... [B]lack women nationally, especially young black women, are facing a shrinking pool of "marriageable" (i.e., employed) black men. This finding supports the hypothesis that the sharp rise of black female-headed families is directly related to increasing black male joblessness. ${ }^{25}$

\section{B. Singular Pathology}

In poverty discourses, such as those set out above, the label "Mother" is modified by her legal relationship (or lack thereof) to a male. Mothers are classified by whether or not they are simgle, a fact that is positioned as significant and even central to the discourses. The $a b-$ sence of the formal legal tie to a male is far more than just a descriptive term or classifying category. It has powerful ideological implications. In addition to providing a basis to determine who is undeserving in our culture, the rhetoric constructs single inotherhood as dangerous and even

24. Working Seminar on Family and American Welfare Policy, The New ConsenSus on Family aNd Welfare: A Community of Self-Reliance 4, 5 (1987) (The American Enterprise Institute for Public Policy Research).

25. W. Wilson, The Truly Disadvantaged: The Inner City, the Underclass, and Public Policy 104-05 (1987). 
deadly, not only to the single inothers and their children, but to society as a whole.

Two recent news articles illustrate the typical ways that popular culture treats the threat of single inotherhood. In the first, the Chancellor of the University of Wisconsin at Madison, Donna Shalala, was reported as stating that unwed teen pregnancy is "an issue that threatens the future of Milwaukee and is as dangerous and crippling to young lives as poho."26 Describing the enormity of the problen1 as "frightening," Shalala warns that "the stakes are very high. The stakes are our future, not only in Milwaukee, but our future as a state."27

Joanne Jacobs, a columnist for the San Jose, California Mercury News, wrote an article entitled "Illegitimacy Biggest Killer Of Our Babies." She asserted that the leading killer of young children in America is not drugs, cancer, or accidents, but illegitimacy. ${ }^{28}$ This article is offensive beyond the author's use of the antiquated term "illegitnnate," a term that suggests that the marital status of the child's mother has inplications for the quality of the child. Jacobs reported the results of a study by Nicholas Eberstadt of Harvard's Center of Population Studies and the American Enterprise Institute. In so doing, she popularized and publicized the rather amazing behef that the high death rate for "illegitimate" children was not related to the mother's age, race, education, or income, but was due to "the lack of care that leads to illegitimacy [and that] also leads to poor care for the kids." 29

Jacobs dutifully hists, although ultinately disagrees with, Eberstadt's conclusions. She also rejects the policy recommendations of Nicholas Davidson that this lack of care warrants such drastic action as the denial of welfare benefits to nothers who "deliberately give birth to and raise a fatherless child." 30 In addition, she rejects Davidson's suggestion to alter the law "to grant divorce only for cause [such as] adultery, abuse or desertion - and to deny wonen custody of their children," thereby removing the "incentive" to divorce provided by easy no-fault divorce, niaternal custody, and mandatory child-support paynients. ${ }^{31} \mathrm{~J}_{2}-$ cobs nonetheless concludes the column with her own normative observation that "we've becoine way too accepting of an 'alternative lifestyle' in which fathers are dispensable. It's bad for kids." 32 col. 6.

26. Teen Pregnancy Called Issue that Threatens State, Milwaukee Sentinel, May 1, 1990, at 1,

27. Id.

28. Jacobs, Illegitimacy Biggest Killer of Our Babies, Wis. ST. J., Feb. 9, 1990, at 11A, col 6.

29. Id.

30. Id.

31. Id.

32. Id. 
These popular characterizations of single motherhood are crude echoes of the images of the single mother prevalent in political, legal, and professional discourses that speculate about the impact of single motherhood on the institution of the family, and ultimately on the fate of our society. We speak of the "broken" family, the "disintegration" of the family, the "crisis" in the family, the "unstable" family, the "decline" of the family, and, perhaps inevitably froin some perspectives, the "death" of the family. Underlying such labels is the specter of single motherhood-statistically on the upswing-pathological and disease-like, contaminating society, contributing to its destruction and degeneration. ${ }^{33}$ With this perspective so pervasive, it is little wonder that many reformers urge efforts to curb the practice of single motherhood. Even liberal commentators such as Irwin Garfinkel of the Institute for Poverty Research are mindful of the role of deterrents and incentives in welfare reform. Garfinkel states that " $[t]$ le problem with providing more aid to singleparent families is that doing so creates incentives for the formation and preservation of single-parent families." 34

Unlike some conservative commentators, Garfinkel recognizes that single-parent families are not necessarily bad:

Of course, it is possible that society is better off-or at least not worse off-as a result of whatever additional single-parent families are created by more favorable treatment of those groups. Not all marriages are made in heaven. Some men beat their wives and children. In some of these cases, all the parties may be better off separate rather than together." 35

Nonetlieless, he concludes that "[d]espite the fact that increases in single parenthood may not be socially permicious, prudence would suggest that in the face of ignorance we should seek to minimize incentives for single parenthood." 36

Single motherhood has been designated as the source of other social phenomena such as crime and poverty. Indeed, in the public's mind, and despite overwhelming evidence to the contrary, ${ }^{37}$ the face of poverty has

33. See supra text accompanying notes 9-10 (statement of Sen. Moymihan).

34. I. GARFinkel, THE Role of ChILd SUPPORT IN ANTIPOVERTY Policy 12 (1982) (Institute for Research on Poverty, Discussion Paper, \#713-82) (on file with author).

35. Id.

36. $I d$.

37. See M. KATZ, supra note 16, at 216-17. The statistics are summarized by Katz:

[M]ost poor people in America do not live in families headed by adolescent mothers or even by women. In 1980,37\% of poor people lived in female-headed families. Poverty is not synonymous with simgle parents. Nor does adolescent pregnancy consume a large share of the social welfare budget or gross national product. In 1980, the money spent on AFDC represented only about $4 \%$ of all the costs of major public assistance and social imsurance programs for the elderly, totally disabled, and all others, and only a fraction of AFDC payments go to adolescent mothers. In 1984, all means-tested cash transfer pay- 
increasingly becoine that of a single mother, particularly the AfricanAmerican single mother.

Single inotherhood represents both the cause and the result of the dismtegration of the family and society; it is a demographic category filled with political and moral significance, and as such is viewed as having both explanatory and predictive powers. This is true not ouly in popular discourse ${ }^{38}$ but in more "reflective" areas of discourse such as the social sciences, pohicy, and law. ${ }^{39}$

ments by federal, state, and local governments used $0.8 \%$ of GNP or two percent of the share of GNP spent by governments.

Consider, next, the question of birth rates. Among blacks, adolescent birth rates have fallen; among whites they have increased. Between 1970 and 1980 , the birth rate of unmarried black women dropped $13 \%$, in contrast to a $27 \%$ increase among unmarried white women. Nonetheless, black marital fertility fell even faster (38\%), which ineans that the fraction of births occurring to unmarried women increased. Among just 15- to 19-year-old black women, the nonmarital fertility rate (births per 1,000 woinen) rose from 76.5 in 1960 to a peak of 90.8 in 1970 and has declined since then; by 1980 it had dropped to 83.0. Among whites, the rate, always lower than blacks', has risen steadily from 6.6 in 1960 to 10.9 in 1970 and $16.0 \mathrm{~m} 1980$. In other words, between 1970 and 1980 , the fertility of unmarried black 15- to 19-year-old women dropped almost 10 pereent, while the rate for unmarried white women of the same age increased by 48 percent. Although the black rate remained more than five times as great as the white, adolescent pregnancy is not an issue just for blacks.

Id. For a debunking of a variety of "welfare myths," see M. EDELMAN, FAMILIES IN PERIL: AN Agenda For Social Change 68-74 (1987).

38. See, e.g., Passell, Economic Watch: Forces in Society, and Reaganism, Helped Dig Deeper Hole for the Poor, N.Y. Times, July 16, 1989, § 1, at 1, col. 4. The article reports the release of a document from the House Ways and Means Committee that shows a decrease in income for the poorest one-fifth of Americans and an increase in income for the most wealthy one-fifth between 1979 and 1987, and asks: "Why is the gap widening?" The author responds:

Frank Levy, a professor at the University of Maryland, cites the growth of households headed by simgle parents who lack the skills and motivation to earn a decent hiving. The figures bear him out: From 1979 to 1987 the number of single parent families hiving below the poverty level rose by 46 percent.

Id. at 20. The article proceeds to cite several other factors, such as the increasing number of women competing for jobs in the work force, foreign competition, and changes in tax laws. Id. However, it is significant that the immediate response was to look to the increase in single inotherhood as responsible for the imcrease in poverty.

39. The preeminence of the demographic category over material and structural circumstances, even when both factors are considered significant, is evident $i \mathrm{~m}$ the work of Renee Monson and Sara McLanahan. The authors state:

[M]ost analyst agree that the proximate causes of poverty in mother-only families are:

(1) the low earning capacity of single mothers; (2) the lack of child support from nonresident fathers; and (3) the paucity of public benefits.

R. Monson \& S. McLanahan, A Father for Every Child: Dilemmas of Creating Gender Equality in a Stratified Society (unpublished paper) (available from author). Nonetheless, as they uncritically note: "The Family Support Act of 1988 attempts to redress [the first two] of these eases." Id. at 1. The authors identify as "[a] major weak link in the current child support system [the] failure to establish paternity for children born to never-narried mothers." Id. The Act attempts to remedy this by "requiring states to (1) increase the proportion of AFDC cases with child support awards; (2) obtain social security numbers from both parents in conjunction with the issuance of birth certificates; and (3) require all parties in contested paternity cases to take a genetic test." Id. The Act also urges states to simphify civil paternity proceedings and gives imcentives for states to set up programs to track down out-of-state fathers. Id. 
Why has this casting of single motherhood as pathological, as a social disease, and as one of the core explanations of poverty been so readily accepted and perpetuated in such a variety of contexts, and by people who occupy a wide range of pohtical viewpoints? It must seem evident to hiberals that this stereotyping may be viewed as misogynist and racist. In attempting to answer this question, I have reached a number of conclusions about the role of idcology in constructing and perpetuating the images of single mothers in poverty discourses. The representation of single inotherhood as pathological is inextricably linked to patriarchical ideology - a constellation of symbols and behefs about the "natural" or "normal" family that is widely shared in our culture and through which all motherhood discourses are processed.

\section{IDEOLOGY AND MOTHERHOOD}

I think of ideology as a rationalizing set of primciples and concepts that link discourses to power. A close examination of discourse will thus reveal implicit aspects of an underlying ideology. Discourses are linguistic framings or stylized appeals to ideology; ideology, therefore, is what defines and structures the contours of discourse. A critical examination of poverty discourse discloses that patriarchy is the dominant family ideology that fixes the core concepts and images about motherliood. Patriarchy also facilitates, and even mandates, the cross-over effect of such discourses. In this regard, the discourses that concern poverty and single motherhood are consistent with otlier stereotypes and myths fashioned under the influence of patriarchical ideology in which the dominant family form is a male-dominated reproductive unit with defined gender roles. Although this traditional image has undergone soine revisions in light of the modern concerns with gender equity and equality, the nuclear family form, with a sexual affiliation between man and woman as the paradigmatic intimate associational bond, is still the focus in policy discourses. Patriarchical ideology may have adapted to twentieth-century shifts in expressions of sexuality and redefinitions of gender roles, but the fundamental composition and nature of the core images reinam constant. Mother and child are defined by their relationship to the patriarch.

When one considers the relationship between motherlood and patriarcliy, it seems that motherliood has always been, and continues to be, a colonized concept-an event physically practiced and experienced by women, but occupied and defined, given content and value, by the core

Feminist critiques in this area are often poorly received. Monson and McLanahan complain, for example, that instead of supporting new child support legislation as "creating a partnership between the family and the state that would help ensure the adequate care of children," feminists have objected to the new law as an intrusion "on women's privacy and sexual freedom." Id. at 7. 
concepts of patriarchical ideology. Single motherhood is viewed as a practice of resistance to patriarchal ideology, particularly because it represents a "dehberate choice" in a world with birth control and abortion. As such, the existence of single motherhood as an ever-expanding practice threatens the hold of the dominant ideology.

\section{A. Patriarchy as Ideology}

I view patriarchy as an ideology constituted by a set of concepts and symbols that are more coinplex and convoluted than the simplistic notion that men are the formal holders of power within the family and society (a parody of patriarchy). Gerda Lerner defines patriarchy as the "manifestation and institutionalization of male dominance over women and children in the family and the extension of male dominance over women in society in general." 40 I question the emphasis that this definition places on "manifestation" and "institutionalization" of dominance. This focus presupposes and mandates that societal structures such as the family becoine the focal point for critical assessinent. Such an approach may foster the behef that structural changes alone can transform society. Yet, it seems essential that we go beyond a structural critique and consider the power of dominant ideology, a more elusive and resistive social and cultural product than any mere structure. It is the power of ideology that explams why an individual can resist or reject structure by, for example, refusing to participate in a nuclear family, but still find herself defined and ultimately controlled by the ideology underlying the structure.

My preoccupation with ideology leads me to be more pessimistic about the possibility for social transformation than social critics who focus on structure. Dominant ideologies are subtly and conclusively expressed and repressed in the very creation and recreation of social norms and conventions. They define the contours of culture and of society and its institutions. A dominant ideology is transmitted through everyday language, symbols, and images, as well as through the operations of formal institutions and structures of power.

Patriarchy is such a dominant ideology. It has as one of its organizing premises the behef that the primary affiliation in society is the sexual bond. In our legal and political culture, consistent with the demands of the ideology, it is this affiliation that is privileged as the paradigmatic manifestation of cormection. In popular culture, sexual expression (particularly heterosexual expression traditionally realized through inarriage) is portrayed as the quimtessential indication of inaturity, coinpleteness,

40. G. Lerner, The Creation of Patriarchy 239 (1986). 
success, and power. Historically, deviance from the heterosexual paradigm brought with it social and even legal sanctions, ${ }^{41}$ as well as condemnation in the discourses of psychology, social work, and medicine. In recent years, the legal and heterosexual aspects of the paradigm have been challenged by demands to consider other forms of sexual intimacy as equally privileged as formal inarriage. Alternative family legislation has been enacted that recognizes sexual affiliations other than heterosexual formal inarriage. ${ }^{42}$ I consider these reforms to be coinphicit with patriarchical ideology, however, because by duplicating the privileging based on heterosexual affiliation, these relationships inerely affirm the centrality of sexuality to the fundamental ordering of society and nature of intimacy. The nexus or affiliating circumstances of these "alternatives," although not the traditional "conjugal family," is still the sexual connection.

Single motherhood, therefore, could be considered deviant and threatening simply because it is a rejection of the primacy of the sexual connection as the core organizing familial concept and the privacy basis for social organization. The very label "single mother" separates some practices of motherhood from the institution of "Mother" by reference to the inother's inarital status. Mother, as constructed and defined in this discourse, is modified by her relationship (formal and legal) to the father. By contrast, the institution when practiced in its "normal" form is not so inodified. No one speaks of a "married mother"; the primary connection of husband and wife is assumed in the unadorned designation of "Inother." It is only the deviant form of motherhood that needs qualification and, by implication, justification. In this process of distinguishing the deviant variation of motherhood from the norm, a compleinentary cluster of stereotypical designated family roles are implied to form the contemporary images of the "ideal" family.

\section{B. The Role and Function of Ideology}

Thus far I have asserted a relationship between ideology and discourses about motherhood. As a methodological point, I have assumed that the study of rhetoric about inotherhood revcals soinething about the existence and content of the dominant ideology. This in turn reveals

41. Legal sanctions are still possible for "deviant" sexual behavior. See, e.g., Bowers v. Hardwick, 478 U.S. 186 (1986) (upholding constitutionality of state statute criminalizing consensual sodomy).

42. See, e.g., MINNEAPOLIS MINN. CODE tit. 7, ch. 142 (1991) (recognizing the relationship of two non-married but committed adult partners); WEST Hollywood CA. MUN. CODE $\$ \S 4220-$ 4228 (1988 \& Supp. 1991) (adopting procedures whereby adult non-married partners can declare themselves "domestic partners"); see also MADISON WIS. GEN. ORDinances $\$ 3.38(25)$ (1988) (providing for the registration of "alternative families"). 
something about the location of power within society. In defining these relationships, I pursue the suggestion made by Terry Eagleton that "[d]iscourses ... produce effects, shape forms of consciousness and unconsciousness, which are closely related to the maintenance or transformation of our existing systems of power."43 Eagleton went so far to assert that ideology can be taken to indicate no more than the connective link between discourse and power. ${ }^{44} \mathrm{I}$ am also influenced by Christine Harrington and Sally Merry who cast legal ideology in terms of the mobilization of "symbolic resources by groups promoting different projects." 45

My interpretation and application of these conceptions of ideology begins with an understanding of ideology as a systein constituted by a complementary collection of symbols, beliefs, and assunptions that in combination rationalize and give meaning to discourses in the context of power. Ideology in this regard can be considered functional-a selection and sorting mecharism in that it provides coherence, structure, and form to social and political discourses. This understanding of ideology as having systemic implications, however, has theoretical as well as practical implications. On a practical level, it means that ideology is more likely to operate as a conservative force. It will serve to tame or doinesticate discourses by exerting a confining pressure on their initial development, ultimately channeling even the most radical ideas into categories approved by the existing conceptual system. Within this perception of ideology, meaningful conflict and competition are confined to the level of discourse. To be labeled "dominant"-as providing the recognized links between power and discourse-an ideology may not be too sharply contested. A dominant ideology, therefore, is relatively stable, although it may be altered over time, adapting in response to the tensions generated by violent or prolonged deinands from discourses.

In addition, if we posit ideology as a system of symbols and beliefs, it must be experienced as both complex and dynannic, which means that it will seldom be totally revealed in the context of a specific political debate or contest of discourses. It also will not be easily expressed abstractly, outside of the context of a specific set of assumptions. As a dynaimic system, ideology represents a process that is not facilely reduced to a finite set of clearly stated primciples that are operational outside of any specific application. A cluster of social and cultural syinbols and beliefs, ideology is referenced in seemingly disassociated discourses; it

43. T. EAGLETON, LITERARY Theory: AN INTRODUCTION 210 (1983).

44. Id. at 73.

45. Harrington \& Merry, Ideological Production: The Making of Community Mediation, $22 \mathrm{~L}$. \& SOC'Y REV. 709, 714 (1988). 
can be imagined as a series of synapses that together form possible permutations for various appeals (discourses) to the institutions of formal power in our society. The definitive shape and content of an ideology is only partially revealed in its symbols: fragmented and shadowed traces discernable within discourses from their initial formnlation to their ultimate translation and transformation within mstitutions of power. ${ }^{46}$

My assertions have implications for the methodology that $I$ have adopted in examining discourses about motherhood. The task is to uncover and understand the appeal to ideological coinponents-the link to power. Ideology is a shared cultural construct. Its core images define the discourses produced by both the proponent of the status quo and its critic. For example, $\mathrm{I}$ have found in examining different discourses about motherhood that the underlying symbols and values are more uniformly shared than the differences in discourses would superficially indicate. Conflicts that are developed and located in these discourses concern the political iniplications or meanings of the symbols and beliefs that comprise the ideology, but do not dispute their existence or potency. Oppositional discourses reference the shared aspects of the ideology in what are attempts to compel and convince.

\section{Conclusion}

An examination of motlerhood in terms of its changing manifestations reveals that patriarchy as an ideology lias adapted to ostensibly cliallenging discourses and absorbed seemingly significant challenges while ensuring the relatively undisturbed continuation of power distributions within the family structure. This adaptation or inodification of patriarchy was necessitated by the "crisis" of the rising divorce rate in the

46. My use of the term "power" in this context is a narrow and explicitly political one-something inanifested in and expressed by a dominant social group within the confines of institutions. In this regard, law and legal institutions are concrete nnanifestations or locations of power, tethered to ideology.

In the context of my examination of poverty discourses, this methodology has deinanded an inquiry into the similarities between liberal and conservative political discourses about welfare and poverty. Both discourses atteinpt to forge links to the core concepts of an underlying ideology, and an examination of seemingly dichotomous rhetorical visions on an issue begins to reveal these key images and concepts. In addition, the threads of discourse by political actors are also reflected in popular discourses, mirrored in professional discourses such as those of the social sciences and psychology as well as other analyses of poverty, including those of the poor themselves. These discourses are all confined to the dominant core concepts of the ideology-a failure to reference those concepts will mean the discourse will lack the coherence forcefully to critique power, to make changes, to punish or to reward.

In addition, on a broader social and legal level, this referencing of core concepts is evident in other areas including discussions about child custody or child abuse and negleet. These discourses also relate to the overarching rationalizing ideology when the subjeet of discussion is motherhood. 
twentieth century. ${ }^{47}$ The traditional family formation was disrupted, but the acceptance of joint custody and the idea of shared parenting has ensured continued male control over children and, through them, over their mothers, even as divorce has becoine available virtually on demand. ${ }^{48}$

Mandatory patermity laws were fashioned in response to the increasing number of women who chose to become single mothers (this has also been designated as a crisis). These laws were first enacted in the context of AFDC single mothers, but are now expanding into other areas of the law. In Wisconsin, for example, under a rhetorical bludgeon that dictates that every child has a "legal right" to a father (or at least to a father's name on a birth certificate), legislation has been passed that requires all single mothers to participate in patermity proceedings. ${ }^{49}$ These proceedings are mandated even if the state is not likely to ever be asked to provide economic support for the child. The core tenets of the ideology of patriarchy-that "natural" families have two parents and that the male position is one of financial primacy and family control-are thus ensured. The inajor architect of the legislation stated:

We have now in Wisconsin a law that I authored that will become the model for the nation regarding paternity. It has as its foundation that every child born in Wisconsin has a legal right to a father. Childreu without legal fathers have started down a shippery slope that leads to poverty. Our new paternity law is a radical departure in that the interests of the child will become equal if not paramount to the interests of the natural parents. The law seeks to ensure that at the time of birth the state and the inother will pursue, for non-1narital births, the establishment of paternity and the subsequeut collection of support.

But the philosophy of the law is not punitive. Rather, it assunies that families are natural and that it is not appropriate to have laws that have as their result that in one out of every two births outside of marriage the child will have no legal father-paternity will never be estabhished. ...

Under our new law the birth certificate will be the vehicle to establish paternity early on. A presuniption of paternity will be created with the filing of a statement. It will go with the birth certificate in inost cases when the baby leaves the hospital. It will provide the basis

47. Even within the confines of the ideal family, the roles that wives and mothers are now expected to play have expanded. Modern female components of the ideal family are now likely to carry briefcases in addition to those cultural artifacts considered essential to present themselves as competent and caring (and therefore, of necessity, married) mothers and alluring wives. The goal of independence and autonomy for the individual has thus been tamed in its feminine presentation; such autonomy contained within the ideal family and confined by other roles is itself no more than a reflection of the resilience of the institution and the attractiveness of its head.

48. See M. Fineman, supra note 2, at 90-94; see also id. at 109-43 (discussing the use of social science information and the role of helping professionals in the resolution of custody disputes).

49. Wis. STAT. $§ 767.45$ (1988). 
for courts to order child support. But most important, it will give that child a legal father.

Both our child support law and our new paternity law are designed to ensure parental responsibility and to help families form and most importantly give uew rights to children. ${ }^{50}$

The Legislator does not mention that the mother's cooperation in this paternity program will require her to reveal details of her sexual and personal life, or risk the potential sanction of incarceration through a court's contempt power. Nor does he note that the legal father's paternal involvement with the child will not be mandated by the court beyond (perhaps) payment of child support. Also absent is the fact that a legal father can exercise legal rights and become an unwanted or even abusive presence in the inother's and child's life merely because he fathered the child.

Changes in behavior precipitated by alterations in divorce laws and women's expanding economic security (which allow them to choose to become simgle mothers) have required the remodeling of patriarchy. The remodeling, however, has not substantially altered, let alone led to the rejection of, the core images of the ideology. The foundation remains stable. Society may now be grudgingly forced to accept smgle-inother households as an unfortunate byproduct of the social and economic dislocations that characterize the latter part of this century, but they are seldom treated as an acceptable, let alone a desirable, family forn. In expressions of popular culture, as well as in public policy, single motherhood may be perceived at best as requiring an uneasy accommodation witl the dommant ideology. The societal aspiration, lowever, remains to complete the "family" by the addition of a inan.

In the context of the treatment of single mothers in poverty discourses, the focus on family forn obscures the economic deprivations that make it difficult for simgle women to raise their children. Rather than addressing their needs as single mothers, reforms tend to try to push them into a model of family life that is imcreasingly discredited, even in the middle class from which it arose. The dommance of family imagery contained in the ideology of patriarchy has required the rejection of economic subsidies that would truly support single mother families. Instead, their deviation must be punished and deterred, and their practice of resistance curtailed.

50. Speaker Tom Loftus of the Wisconsin State Legislature, Remarks to the National Child Support Enforcement Association, New Orleans, La. (Aug. 23, 1988) (on file with author). 